\title{
Acquired Immunodeficiency Syndrome (AIDS) and Women's Health
}

\author{
Sarmad Muhammad Soomar* \\ Aga Khan University School of Nursing \& Midwifery, Pakistan
}

Submission: January 04, 2019; Published: March 27, 2019

*Corresponding author: Sarmad Muhammad Soomar, Aga Khan University School of Nursing \& Midwifery, Pakistan

\begin{abstract}
Increased rates of Acquired Immunodeficiency Syndrome (AIDS) are overall impacting global health. Especially women in terms of issues related to sexual health autonomy and others. Overcoming this issue to improve health status of women require various strategic planning. The write up considers the current status and outbreaks of the disease in Pakistan. Moreover, in the paper you will find details of the disease and its relationship with women's health in lieu of not only physical but social issues too. Also, the recommendations for strategic planning mentioned in the paper are achievable and immensely helpful to work on.
\end{abstract}

Keywords: Acquired Immunodeficiency Syndrome; Women; Health

\section{Introduction}

The global burden of disease has increased with the pace of time. Whereas, combating different communicable diseases is a big public health challenge. Acquired Immunodeficiency Syndrome (AIDS) is one of these challenging diseases. Fighting with AIDS itself is an unmet goal and a huge community health issue. A United Nations (UN) report published last year states that millions of lives have been lost because of the presence of AIDS during the year 2016 [1].

AIDS is affecting all sorts of populations and unfortunately, a dense female population is bearing harmful consequences of this disease. While recalling a recent incident, followed on national news channels regrading one of the Pakistani cities having Human Immunodeficiency Virus (HIV) positive citizens, includes a good number of women who were found bearing the virus and the disease upon testing [1]. For those who are still indulge in selfmade details or misconceptions about AIDS, let us share that the disease is caused because of retrovirus, which impairs the function of immune system and the carrier becomes more vulnerable to other diseases as well [2]. Also, the main responsible events of its occurrence are unprotected sex, sharing of infected needles, un-screened blood transfusion and through vertical transmission as well. In addition, the progression of disease development can take up to ten years as it goes through various phases of disease progression $[2,3]$. Many virus carriers might not get the disease at the moment of contact.

\section{AIDS and Women}

Signs and symptoms of AIDS exhibited in female especially are uniform around the globe. These symptoms can be characterized as Physical and Psychological. Common physical signs are diarrhea, nausea and/or vomiting, cough, fever, pain, neuropathy, weight loss, skin problems, and gynecological issues. Anxiety, depression and sleep disturbances are some psychological symptoms usually observed in women having AIDS [3]. In 2014, 94000 cases were identified with AIDS among which 26000 were females above the age of 15. The global statistics of AIDS has drastically changed the disease that largely affected the men in past decades; it is now affecting women in a growing number $[4,5]$. Women are considered as the most vulnerable population to AIDS in regard to a variety of determinants [5].

Many of the women are not able to decide about their sexual health matters, as patriarchy is dominantly seen in our culture $[5,6]$. This makes them more prone to getting diseases like AIDS, where they cannot speak up about screening or stopping unhygienic practices or may support use of condoms [7]. Women who are economically less privileged or who have experienced gender-based violence are also moderators in AIDS progression and development. Majority of these social issues result in lack of knowledge about the disease, un safe sex practices or multiple sex partners, forced sex and inaccessibility to health care facility, which ultimately increases the risk of AIDS in female gender $[6,7]$.

Rising growth of HIV in women is because their physical makeup. The cervical mucosa and high level of immune cells in genitalia are associated with acquisition of HIV [8]. Physiological changes during pregnancy and lowered immunity makes pregnant women prone to have AIDS in comparison of lactating or other women [7]. Some studies suggest that hormonal contraceptives like progesterone are also related with development of HIV in 
women [9]. Women involved in transactional sex or who are Injection Drug Users (IDUs) are at higher risk too [5].

\section{Recommendations and Conclusion}

Overcoming HIV \& AIDS in women requires a strategic healthcare planning that involves security of their overall health and wellbeing. Suggesting alternative forms of contraception like condoms or diaphragms instead of hormonal therapies or drug substitution therapy for outcome-based prevention in IDUs [8] Improving socio economic issues is much crucial in decreasing HIV in women. Working on providing loan and micro finances to women in order to grow own economy and debating on their social taboos or developing their self-esteem through small business or educational opportunities, with proper sex education would dignify them and empower them to speak up for the health rights and prevent AIDS [5,8]. In conclusion, it is predominately seen that presence of AIDS in women can be so significant to deal with in order to achieve better outcomes of health.

\section{References}

1. Geo News Tv - Health (2018) 22 people test positive for HIV in Sargodha village.

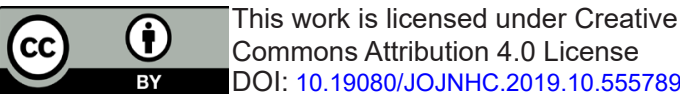

2. World Health Organization (2015) HIV AIDS.

3. Nicholas PK (2014) Women and HIV: Symptoms and Quality of Life in Women.

4. UNAIDS (2014) HIV and AIDS estimates.

5. Ramjee G, Daniels B (2013) Women and HIV in sub-Saharan Africa. AIDS research and therapy 10(1):30.

6. Ali TS, Krantz G, Gul R, Asad N, Johansson E. et al. (2011) Gender roles and their influence on life prospects for women in urban Karachi, Pakistan: a qualitative study. Glob Health Action Dec 4(1):7448.

7. Carter AJ, Bourgeois S, O’Brien N, Abelsohn K, Tharao W. et al. (2013) Women-specific HIV/AIDS services: Identifying and defining the components of holistic service delivery for women living with HIV/AIDS] Int AIDS Soc. 16(1): 17433.

8. Dellar RC, Dlamini S, Karim QA (2015) Adolescent girls and young women: key populations for HIV epidemic control. J Int AIDS Soc 18(2S1).

9. Heffron R, Donnell D, Rees H, Celum C, Mugo N. et al. (2012) Use of hormonal contraceptives and risk of HIV-1 transmission: a prospective cohort study. Lancet Infect Dis 12(1): 19-26.

\section{Your next submission with Juniper Publishers will reach you the below assets}

- Quality Editorial service

- Swift Peer Review

- Reprints availability

- E-prints Service

- Manuscript Podcast for convenient understanding

- Global attainment for your research

- Manuscript accessibility in different formats

( Pdf, E-pub, Full Text, Audio)

- Unceasing customer service

Track the below URL for one-step submission https://juniperpublishers.com/online-submission.php 